УДК 556.161:556.166

\title{
ВЛИЯНИЕ КЛИМАТИЧЕСКИХ ИЗМЕНЕНИЙ НА МАКСИМАЛЬНЫЕ УРОВНИ ПЕРИОДА ПОЛОВОДЬЯ РЕКИ АБАКАН
}

\author{
Галахов Владимир Прокопьевич1, \\ galahov@iwep.ru \\ Ловцкая Ольга Вольфовна1, \\ lov@iwep.ru
}

\author{
Мардасова Елена Владимировна², \\ mardasova_ev@mail.ru \\ 1 Институт водных и экологических проблем СО РАН, \\ Россия, 656038, г. Барнаул, ул. Молодежная, 1. \\ 2 Алтайский государственный университет, \\ Россия, 656049, Барнаул, пр. Ленина, 61.
}

\begin{abstract}
Актуальность работы обусловлена воздействием изменений климата на гидрологические режимы рек южной Сибири, увеличением повторяемости опасных гидрологических явлений. Наблюдаемые и прогнозируемые изменения в режимах половодий вызываются множеством факторов и требуют различных подходов для характеристики типов этих изменений.

Цель: стохастическое моделирование сумм твердых осадков в исследуемом бассейне р. Абакан, установление их связи с максимальными уровнями воды в р. Абакан периода половодья в условиях пространственно-временной изменчивости гидрометеорологических фракторов.

Методы: комплексный географро-гидрометеорологический анализ, выявление зависимостей по данным многолетних гидрометеорологических наблюдений с использованием методов математической статистики, а также методики оценки количества осадков в бассейне с учетом орографический добавки к скорости вертикальных движений во фронтальной зоне, разработанной В.П. Галаховым.

Результаты. Основным фрактором формирования максимальных уровней периода половодья является количество зимних осадков. Обильные жидкие осадки на спаде половодья могут вносить значительные коррективы в максимальные уровни. Однако для бассейнов горных рек юга Западной и Восточной Сибири в последние десятилетия в связи с климатическими изменениями отмечается влияние условий промерзания почвогрунтов в осенний период на формирование максимальных уровней вследствие снеготаяния. Для бассейнов со значительной долей предгорных равнин в отдельные годы возможно уменьшение максимальных уровней периода половодья. Для бассейнов, имеющих в основном горный ландшафрт, подобного эфффекта не наблюдается. Разработана методика расчета сумм зимних ежегодных осадков в бассейне Абакана, учитывающая фризические особенности формирования осадков в горах, в частности орографрическую добавку к скорости вертикальных движений. На примере независимых данных показано, что алгоритмы расчета максимальных уровней за счет снеготаяния, основанные на регрессионных зависимостях, не всегда дают адекватные результаты. Необходима их корректировка с учетом процессов промерзания на предгорной равнине. Для получения общей статистической зависимости требуются дополнительные данные наблюдений.
\end{abstract}

\section{Ключевые слова:}

Бассейн реки Абакан, зимние осадки, орографическая добавка, скорость вертикальных движений, максимальные уровни.

\section{Введение}

Пространственно-временная изменчивость гидрометеорологических факторов, оказывающих существенное влияние на формирование гидрологического режима водных объектов, серьезно усложняет решение задач гидрологического прогнозирования [1].

На начальном этапе формирования системы прогнозирования паводков и половодий широко используются стохастические (статистические) модели, основанные на регрессионной связи уровня воды с атмосферными осадками [2-5].

Более сложная статистическая модель множественной регрессии предложена в [6] для горной части бассейна реки Абакан. Однако существенным недостатком подобного подхода являются «жесткие» статистические связи, которые не учитывают наблюдающихся в последнее время климатических изменений [7-10]. В [8] выделены два временны́х интервала, отвечающих смене знака тенденций климатических изменений в течение тридцати лет (1981-2011 гг.), и отмечено перераспределение влияния различных типов элементарных циркуляционных механизмов, обусловливающих выпадение осадков.

По нашему мнению, более гибким является подход, базирующийся на расчете сумм твердых осадков и оценке влияния жидких осадков на спаде половодья с учетом условий промерзания почвы, рассмотренный в [11-15]. Такой подход позволяет учитывать не только количество осадков, но и условия их формирования в осенний и весенний периоды. В [16] исследуются связи между характеристиками сезонномерзлого слоя и климатическими характеристиками холодного периода года, в информационных бюллетенях АО «Томскгеомониторинг» и с 2018 г. ФГБУ «Гидроспецгеология» - филиал «Сибирский региональный центр ГМСН» - приведена актуальная ин- 
формация о состоянии снежного покрова и глубине промерзания грунтов на территории Сибирского федерального округа $[17,18]$.

В статье рассматривается применение разработанной авторами методики для оценки максимальных уровней периода половодья реки Абакан [19].

\section{Объект исследования}

Река Абакан является левым притоком Енисея и относится к одной из крупнейших рек юго-запада Восточной Сибири. Бассейн р. Абакан (площадь 32000 км$^{2}$ ) целиком находится на территории Республики Хакасия, занимая почти 52 \% ее площади.

Бассейн р. Абакан располагается в пределах Алтае-Саянской горной страны и ограничен с запада и северо-запада собственно Абаканским хребтом, с юго-востока - отрогами Западного Саяна. В прителецком районе бассейна р. Абакан отмечаются наибольшие абсолютные высоты: более 2000 м с типичным альпинотипным рельефом. К северу от прителецкого района абсолютные высоты уменьшаются до 1500-2000 м. С северо-востока бассейн ограничен Минусинской котловиной. В верховьях долина Абакана ассиметрична. Река Большой Абакан прижата к левому борту, поэтому притоки, впадающие в Абакан с этого борта, имеют короткие и крутые долины. Правый борт, с наиболее крупными притоками Малый Абакан и Она, более приподнят по сравнению с левым бортом. Абсолютные высоты стыка отрогов Западного Саяна и Шапшальского хребта достигают высот немногим менее 3000 м (например, г. АжуТайга (верховья Малого Абакана) - 2858 м, г. Карагош (верховья Оны) - 2981 м). Реки имеют преимущественно плоскодонные долины [20].

В пределах Минусинской котловины хорошо выделяются два высотно-ландшафтных пояса - степной и лесостепной.

Зимы в данном районе суровы, летние сезоны непродолжительны. Перенос воздушных масс происходит в основном с запада на восток. Временами наблюдаются выходы циклонов с юга и юго-запада.

Наибольшее годовое количество осадков (от 700 до 1750 мм) выпадает на восточных (подветренных) склонах Абаканского хребта и западных (наветренных) склонах Западного Саяна. Начало зимы приурочено к ноябрю, сход снежного покрова - в зависимости от абсолютной высоты к апрелю-маю. Продолжительность залегания снежного покрова в котловине составляет 140 дней, в высокогорье - до 240 [20, 21].

\section{Постановка задачи и исходные данные}

Основной целью работы является стохастическое моделирование сумм твердых осадков в исследуемом бассейне и их связь с максимальными уровнями воды в р. Абакан периода половодья в условиях пространственно-временной изменчивости гидрометеорологических факторов.

Для этой цели использованы материалы гидрологических и метеорологических наблюдений, находящиеся в открытом доступе. Гидрологическая информация (средние суточные уровни на гидропостах $\mathrm{p}$.
Абакан - г. Абаза и р. Абакан - г. Абакан) получена из Гидрологических ежегодников (1966-1987 гг.) [22]. Метеорологическая информация (месячные суммы осадков на метеорологических станциях и постах, средние суточные температуры и суточная сумма осадков) - из Метеорологических ежемесячников [23]. Для получения данных за 2004-2018 гг. использованы интернет-ресурсы [24-27].

\section{Методика расчета}

Для оценки суммы зимних осадков чаще всего используются высотные зависимости [28]. Однако их применение не всегда оправдано, поскольку верхние высотные зоны, как правило, не обеспечены наблюдениями.

В $[29,30]$ показано, что величина твердых осадков зависит от скорости вертикальных движений во фронтальной зоне. Во время пересечения орографических барьеров (горных хребтов) на основе относительно простой кинематической модели движения воздушных масс можно рассчитать орографическую добавку к скорости вертикальных движений. Достаточно подробное описание алгоритма модели движения воздушной массы в условиях сложной орографии приведено в монографии [19].

Успешный расчет средних многолетних осадков за холодный период в бассейне реки Чарыш $[31,32]$ на основе использования орографической добавки к скорости вертикальных движений позволил применить аналогичную методику для бассейна реки Абакан.

Для оценки ежегодных величин осадков за холодный период в бассейне р. Абакан с помощью гидрологически корректной цифровой модели рельефа [33] определены границы водосборного бассейна, построена матрица орографической добавки к скорости вертикальных движений (рис. 1) и рассчитана величина орографической добавки в узловых точках (шаг на местности $25 \times 25$ км) (табл. 1). Для оценки количества осадков за холодный период в бассейне р. Абакан установлена зависимость их суммы по данным гидрометеорологических станций (ГМС) с добавкой к скорости вертикальных движений за счет орографии. Подробный алгоритм расчета орографической добавки и текст компьютерной программы, реализующей разработанный алгоритм, приведены в [19].

\section{Оценка максимальных уровней периода половодья}

Прежде чем переходить к оценке максимальных уровней периода половодья, вызванных таянием снега, рассмотрим зависимость подъема уровней на гидропосту р. Абакан - г. Абакан от количества жидких осадков, выпавших на спаде половодья (по метеостанции Прииск Неожиданный) за 1966-1987 гг. Достоверными будем считать данные за конец мая июль (рис. 2). В случае использования более ранних дат за паводок может быть принят подъем уровней воды, вызванный совместным влиянием тающего снега и жидких осадков.

На рис. 3 показаны максимальные уровни воды за те же годы наблюдений, вызванные таянием снега. 
Таблица 1. Список гидрометеорологических станиий, используемых для оценки количества осадков в бассейне p. Абакан [34]

Table 1. List of weather stations used to estimate precipitation in the Abakan river basin [34]

\begin{tabular}{|l|c||l|c||l|c|}
\hline $\begin{array}{c}\text { Гидрометеостанции } \\
\text { Weather stations }\end{array}$ & $\mathrm{Vz}$ & $\begin{array}{c}\text { Гидрометеостанции } \\
\text { Weather stations }\end{array}$ & $\mathrm{Vz}$ & $\begin{array}{c}\text { Гидрометеостанции } \\
\text { Weather stations }\end{array}$ & $\mathrm{Vz}$ \\
\hline Курагино/Kuragino & 0,005 & Бея/Beya & $-0,27$ & Шира/Shira & $-0,27$ \\
\hline Ермаковское/Ermakovskoe & 0,005 & Абаза/Abaza & $-0,18$ & Хакасская/Khakasskaya & $-0,27$ \\
\hline Ненастная/Nenastnaya & 0,50 & Минусинск/Minusinsk & $-0,75$ & Неожиданный/Neozhidanny & 0,2 \\
\hline Коммунар/Kommunar & 0,25 & Oленья Речка/Olenya Rechka & 0,3 & Tаштып/Tashtyp & $-0,27$ \\
\hline Уйбат/Uybat & $-0,27$ & \multicolumn{3}{|l}{} \\
\hline
\end{tabular}

$V z$ - величина орографической добавки, $\mathrm{m} / \mathrm{c}$ /the value of orographic correction, $\mathrm{m} / \mathrm{s}$.

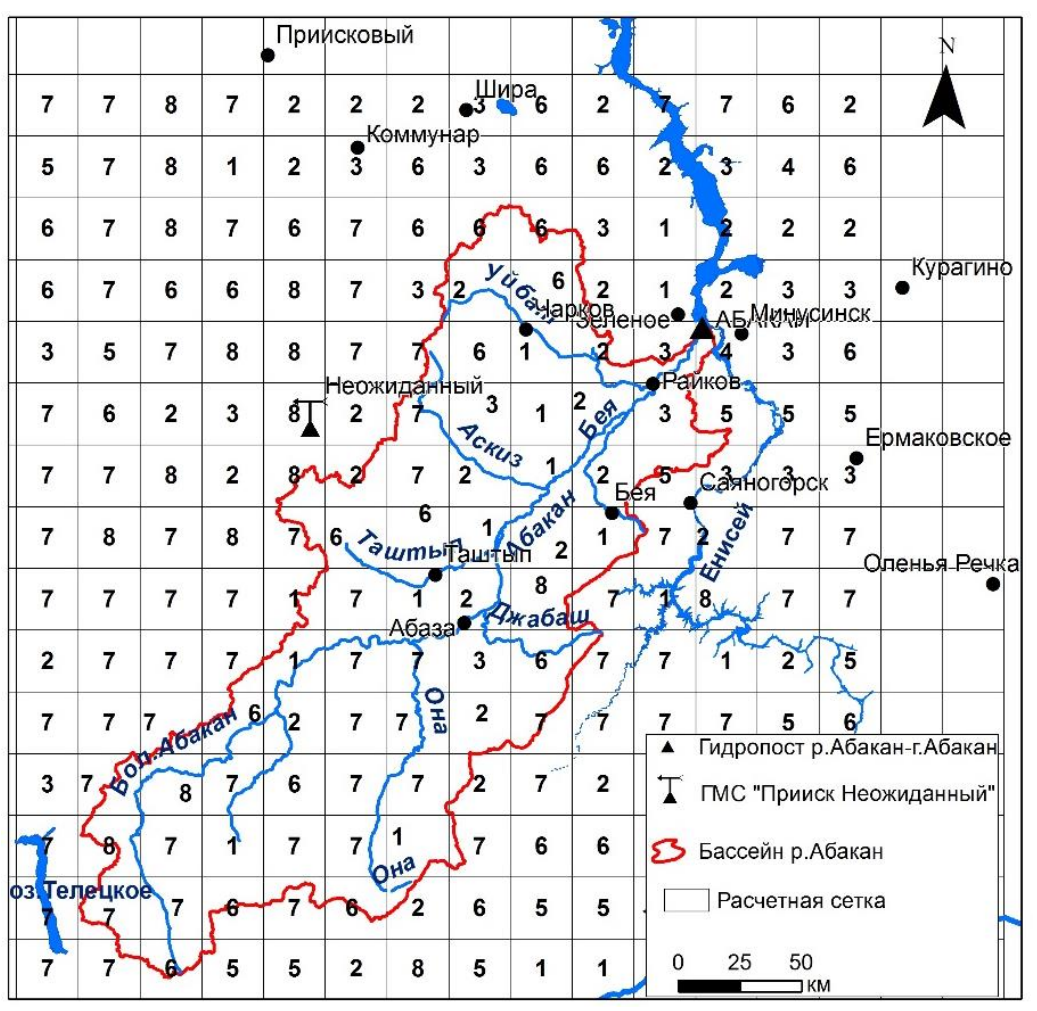

Pис. 1. Матрица для определения орографической добавки к скорости вертикальных движений (м/с): 1) -0,75; 2)0,27 ; 3) -0,055; 4) $-0,025$; 5) 0,005; 6) 0,055 ; 7) 0,3; 8) 0,75

Fig. 1. Matrix of the orographic correction to the velocity of vertical movements $(\mathrm{m} / \mathrm{s}): 1)-0,75 ; 2)-0,27 ; 3)-0,055 ; 4)-$ 0,025 ; 5) 0,005 ; 6) 0,055 ; 7) 0,3 ; 8) 0,75

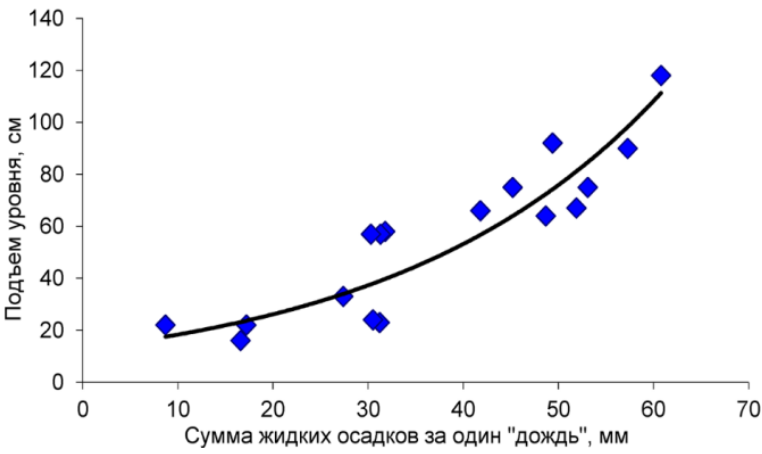

Pис. 2. Максимальные амплитуды подъема уровней воды за счет выпадения жидких осадков $\left(y=12,85 e^{0,036 x}, R^{2}=0,78\right)$. «Один дождь»период прохождения отдельной фронтальной зонь

Fig. 2. Maximum amplitudes of water level rise due to liquid precipitation $\left(y=12,85 e^{0,036 x}, R^{2}=0,78\right)$. "A single rain» is the period of a frontal zone passage

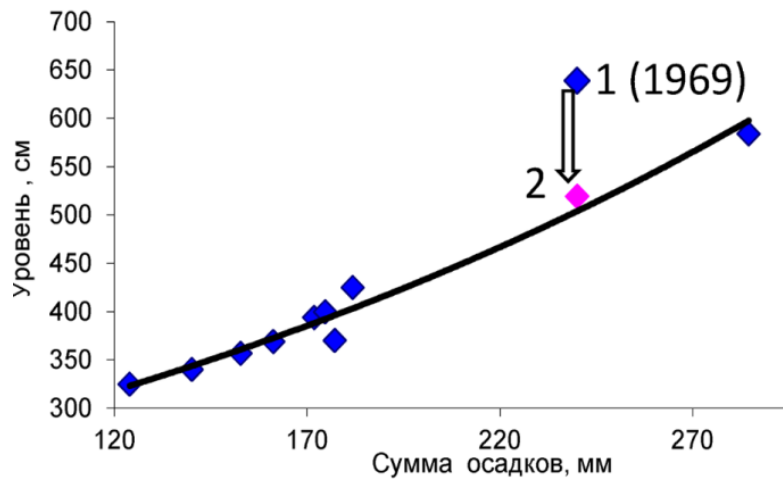

Pис. 3. График связи максимальных уровней воды-(формируемых вследствие снеготаяния) и суммы твердых осадков $\left(y=200,97 e^{0,0038 x}, R^{2}=0,97\right)$

Fig. 3. Dependence of snowmelt-induced maximum water levels on solid precipitation amount $\left(y=200,97 e^{0,0038 x}, R^{2}=0,97\right)$ 
На примере 1969 г. рассмотрим применение разработанного алгоритма для оценки максимальных уровней периода половодья, обусловленных снеготаянием.

Максимальный уровень воды в 1969 г. наблюдался 31 мая и равнялся 639 см [35]. Однако в период с 23 по 30 мая выпало 65,3 мм осадков. В соответствии с рис. 2 это количество жидких осадков вызывает подъем уровня на 120 см (точка 1 на рис. 3). Тогда только снеготаяние должно обеспечить уровень (639-120=519 см) - точка 2 на рис. 3, т. е. жидкие осадки «наложились» на интенсивное таяние, что и вызвало подъем максимального уровня. С учетом поправки на влияние жидких осадков данные по 1969 г. соответствуют представленному на рис. 3 графику.

\section{Проверка разработанного алгоритма} на независимых данных (2005-2018 гг.)

В табл. 2 приведены средние по бассейну суммы твердых осадков с учетом орографической добавки и максимальные наблюдаемые уровни на гидропосту р. Абакан-г. Абакан по данным 2005-2018 гг.

Таблица 2. Рассчитанная сумма твердых осадков в бассейне р. Абакан и максимальные уровни воды вследствие снеготаяния

Table 2. Calculated amount of solid precipitation in the Abakan river basin and snowmelt-induced maximum water levels

\begin{tabular}{|c|c|c|c|c|}
\hline $\begin{array}{l}\text { Год } \\
\text { Year }\end{array}$ & $\begin{array}{c}\text { Сумма осадков, мм } \\
\text { (ноябрь-март) } \\
\text { Precipitation amount, } \\
\text { mm (November-March) }\end{array}$ & $\begin{array}{c}\text { Максимальный } \\
\text { уровень, см } \\
\text { Maximum level, } \\
\mathrm{cm} \\
\end{array}$ & $\begin{array}{c}\text { Дата максимального уровня } \\
\text { за счет снеготаяния } \\
\text { Date of snowmelt-induced maxi- } \\
\text { mum levels }\end{array}$ & $\begin{array}{c}\text { Расчетная зависимость суммы } \\
\text { осадков от орографической добавки } \\
\text { Calculated dependence of precipita- } \\
\text { tion amount on orographic correction }\end{array}$ \\
\hline $2004-2005$ & 147,5 & 367 & 30.04 & \multirow{5}{*}{$\begin{array}{c}\text { Экспоненциальная } \\
\text { Exponential }\end{array}$} \\
\hline $2005-2006$ & 196,9 & 468 & 18.05 & \\
\hline 2006-2007 & 219,1 & 342 & 21.04 & \\
\hline $2007-2008$ & 155,8 & 334 & 24.05 & \\
\hline $2008-2009$ & 180,3 & 349 & 22.05 & \\
\hline $2009-2010$ & 204,9 & 420 & 8.06 & \multirow{2}{*}{ Линейная/Linear } \\
\hline $2010-2011$ & 214,3 & 415 & 19.05 & \\
\hline $2011-2012$ & 138,4 & 329 & 5.05 & \multirow{4}{*}{$\begin{array}{c}\text { Экспоненциальная } \\
\text { Exponential }\end{array}$} \\
\hline 2012-2013 & 225,2 & 325 & 14.06 & \\
\hline 2013-2014 & 165,8 & 337 & 29.05 & \\
\hline 2014-2015 & 191,0 & 381 & 7.06 & \\
\hline $2015-2016$ & 218,7 & 325 & 1.06 & Линейная/Linear \\
\hline $2016-2017$ & 193,2 & 377 & 19.05 & Экспоненциальная/Exponential \\
\hline $2017-2018$ & 189,7 & 379 & 31.05 & Линейная/Linear \\
\hline
\end{tabular}

Примечание. Количество твердых осадков вычислялось с учетом орографической добавки по экспоненциальному или линейному уравнению регрессии в зависимости от величиньл коэффициента детерминации [36]. Для расчетов используется уравнение регрессии с больиим значением.

Note. The amount of solid precipitation was calculated with consideration for the orographic correction using an exponential or linear regression equation depending on determination coefficient value [36]. The regression equation with a larger value with a larger value of $R^{2}$ is used for calculations.

Экспоненциальная зависимость $y=a e^{b x}$, используемая для расчета суммы осадков с ноября по май, обеспечена наблюдениями (орографической добавкой по метеостанциям) от $-0,75$ до $+0,50$ м/с (табл. 1). Дополнительно в матрице орографической добавки [34] имеются три точки, сведения по которым не приведены в табл. 1, с орографической добавкой $+0,75 \mathrm{~m} / \mathrm{c}$. По данным 1966-1987 гг. проанализирован вид экспоненциальной зависимости. Установлено, что коэффициент $b$ изменяется от 2,22 (1981-1982 гг.) до 3,66 (1973-1974 гг.). При $b>3$ и $x \geq 0,75$ наблюдается резкий рост экспоненциальной функции, приводящий к выходу ее из области допустимых «естественных» значений осадков (рис. 4, график 1). Поэтому экспоненциальная функция при $x=0,75$ в некоторых случаях заменяется линейной функцией. Проверка проводилась следующим образом: по точкам с орографической добавкой от $+0,2$ до $+0,5$ строилась зависимость $y=a x+b$ и сравнивались величины сумм осадков при орографической добавке $+0,75 \mathrm{~m} / \mathrm{c}$. Если разница была небольшой (рис. 4, график 2), то использовались значения, полученные по экспоненциальной функции, в случае значительных расхождений при $\mathrm{Vz}=+0,75$ сумма осадков определялась по зависимости $y=a x+b$.

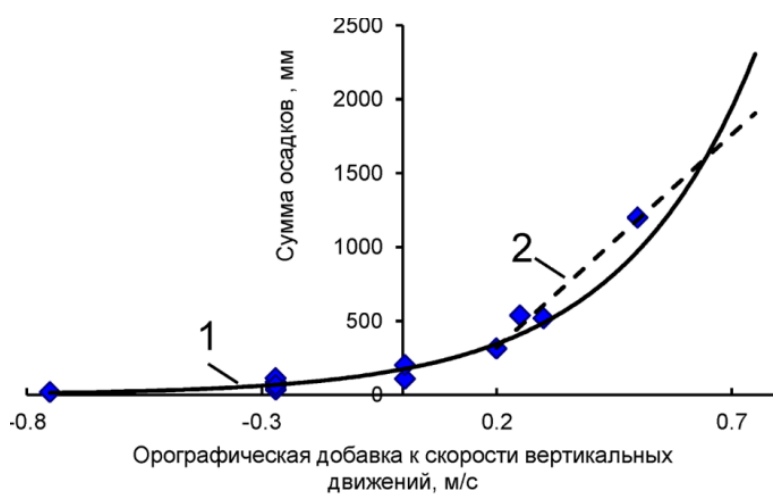

Pис. 4. Графики связи орографической добавки и суммь осадков за ноябрь-май 1971-1972 г2.

(1: $y=172,75 e^{3,46 x}, R^{2}=0,91$;

$\left.2: y=2883,5 x-257,75, R^{2}=0,97\right)$

Fig. 4. Graphs of relationships between orographic correction and precipitation (November-May 1971-1972) $\left(1: y=172,75 e^{3,46 x}, R^{2}=0,91\right.$; $\left.2: y=2883,5 x-257,75, R^{2}=0,97\right)$ 
Аналогичным образом проверялся период с 2004-2005 по 2017-2018 гг. В 2008 г. при Vz=0,5 м/с сумма твердых осадков по экспоненциальной зависимости равна 560 мм; а при $\mathrm{Vz}=0,75 \mathrm{~m} / \mathrm{c}-1200$ мм. Естественно в природе подобного резкого увеличения не может быть, поэтому в соответствии с зависимостью $y=a x+b$ сумма осадков при орографической добавке $+0,75$ м/сек принята 650 мм.

\section{Обсуждение результатов}

При анализе максимальных уровней от таяния снега в бассейне реки Чарыш установлено, что на их формирование значительное влияние оказывает промерзание на начальном этапе снегонакопления. Для р. Чарыш, имеющей значительную долю предгорной равнины в общей площади бассейна, осеннее промерзание является одним из лимитирующих факторов формирования стока половодья. Для р. Ануй, бассейн которой представляет собой низкогорья и среднегорья, влияния осеннего промерзания на сток половодья не обнаружено [37].

Территория бассейна $\mathrm{p}$. Абакан, расположенного в пределах Алтае-Саянской горной страны, характеризуется наличием двух крупных морфологических единиц (предгорная равнина и низкогорьесреднегорье). Проанализируем влияние осеннего промерзания на сток половодья на морфологически различных участках р. Абакан.

На основе полученных материалов построена зависимость максимальных уровней в створе АбаканАбакан от величины зимних осадков за счет снеготаяния (рис. 5). Как видим, некоторые точки «отскакивают» от графика. Анализ данных по метеостанции
Прииск Неожиданный показал, что по условиям снегонакопления годы, данные за которые существенно отклоняются от регрессионной кривой (рис. 5), ничем не отличаются от остальных лет. Рассмотрим условия формирования снежного покрова на метеостанциях и осадкомерных постах бассейна р. Абакан, попадающих в разные морфологические зоны.

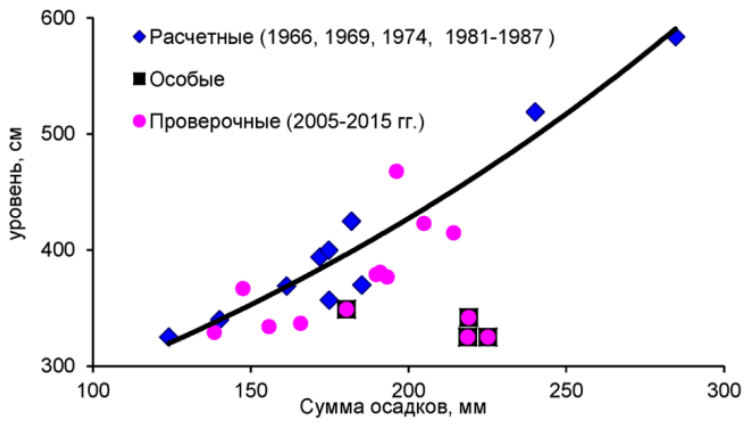

Рис. 5. Зависимость максимальных уровней в створе p. Абакан-г. Абакан от суммы твердых осадков (по бассейну) $\left(y=198,78 e^{0,0038 x}, R^{2}=0,93\right)$

Fig. 5. Dependence of maximum levels at the AbakanAbakan site on solid precipitation amount (for the basin) $\left(y=198,78 e^{0,0038 x}, R^{2}=0,93\right)$

\section{Метеостанция Абакан}

Метеостанция Абакан находится в центральной части Минусинской котловины, на высоте 250 м над уровнем моря. Начальный этап формирования снежного покрова в бассейне реки Абакан (по данным метеостанции Абакан) отображен в табл. 3.

Таблица 3. Начальный этап формирования снежного покрова в бассейне реки Абакан (по данным метеостанции Абакан)

Table 3. Initial level of snow cover formation in the Abakan river basin (according to the data from the Abakan w.s.)

\begin{tabular}{|c|c|c|c|c|c|c|c|}
\hline $\begin{array}{c}\text { Осень, год } \\
\text { Fall, year }\end{array}$ & $\begin{array}{c}\text { Даты первых } \\
\text { снегопадов } \\
\text { Dates of first } \\
\text { snowfalls }\end{array}$ & $\begin{array}{c}\text { Сумма осадков, мм } \\
\text { Precipitation amount, } \\
\text { mm }\end{array}$ & $\begin{array}{c}\text { Высота снега, } \\
\text { см }^{1} \\
\text { Snow depth, } \\
\mathrm{cm}^{1}\end{array}$ & $\begin{array}{c}\text { Осень, год } \\
\text { Fall, year }\end{array}$ & $\begin{array}{c}\text { Даты первых } \\
\text { снегопадов } \\
\text { Dates of first } \\
\text { snowfalls }\end{array}$ & $\begin{array}{c}\text { Сумма осадков, мм } \\
\text { Precipitation amount, } \\
\text { mm }\end{array}$ & $\begin{array}{c}\text { Bысота снега, } \\
\text { см }^{1} \\
\text { Snow depth, } \\
\mathrm{cm}^{1}\end{array}$ \\
\hline 2004 & $5-6.11$ & 1,5 & 1 & 2012 & $5-9.11$ & 7,2 & 5 \\
\hline 2005 & $3-11.11$ & 3,5 & 2 & 2013 & 25.11 & 2,7 & 2 \\
\hline 2006 & 18-23.11 & 6,7 & 5 & 2014 & $18-19.11$ & 0,7 & 0 \\
\hline 2007 & 10.11 & 3,8 & 2 & 2015 & 2-4.11 & 11,3 & 8 \\
\hline 2008 & 9-16.11 & 6,4 & 4 & 2016 & $12.10-5.11$ & 16,7 & 11 \\
\hline 2009 & $4-5.11$ & 2,1 & 1 & 2017 & 9-15.11 & 1,9 & 1 \\
\hline 2010 & 18.11 & 0,4 & 0 & 2018 & 25.11 & 1,0 & 1 \\
\hline 2011 & 9.11 & 1,7 & 1 & & & & \\
\hline
\end{tabular}

${ }^{1}$ Высота снега (см) вычисляется по сумме осадков с учетом плотности снега $\left(\rho=0,15\right.$ г/ $\left.\mathrm{cm}^{3}\right)$.

${ }^{I}$ Snow depth $(\mathrm{cm})$ is calculated from precipitation total due to the snow density $\left(\rho=0,15 \mathrm{~g} / \mathrm{cm}^{3}\right)$.

Годы, указанные в выделенных строках, полностью соответствуют особым «точкам» рис. 5. Как видно, перед сильными осенними морозами (ниже $10{ }^{\circ} \mathrm{C}$ ) снег толщиной 4-5 см препятствует сильному промерзанию почвогрунтов, поэтому в весенний период часть воды впитывается, не формируя значительного подъема воды.

Таким образом, даты первых снегопадов являются идентификаторами промерзания. Отсутствие осеннего промерзания уменьшает максимальные уровни на 40-120 см в зависимости от количество твердых осадков, выпавших в осенне-зимний период (рис. 6).
Несмотря на то, что условия по снегонакоплению на метеостанции Абакан позволили объяснить отклонения от графика на рис. 5, использование данных этой метеостанции для прогнозирования максимальных уровней в устье р. Абакан может вызвать серьезные ошибки, т. к. разница в снегонакоплении в годы с различными условиями промерзания весьма невелика.

Гидрологический пост р. Абакан - 2. Абаза (с проведением метеорологических наблюдений) расположен в межгорной котловине, в верхнем течении реки Абакан. Высота метеоплощадки над уровнем моря 447 м. Водосбор р. Абакан до створа p. Абакан- 
2. Абаза целиком представляет собой низкогорья и среднегорья, в отличие от нижнего участка, расположенного в предгорной равнине (Минусинская котловина). Зависимость максимальных уровней (формируемых вследствие снеготаяния) в створе р. Абаканг. Абаза от суммы твердых осадков (рис. 7) свидетельствует об отсутствии влияния осеннего промерзания.

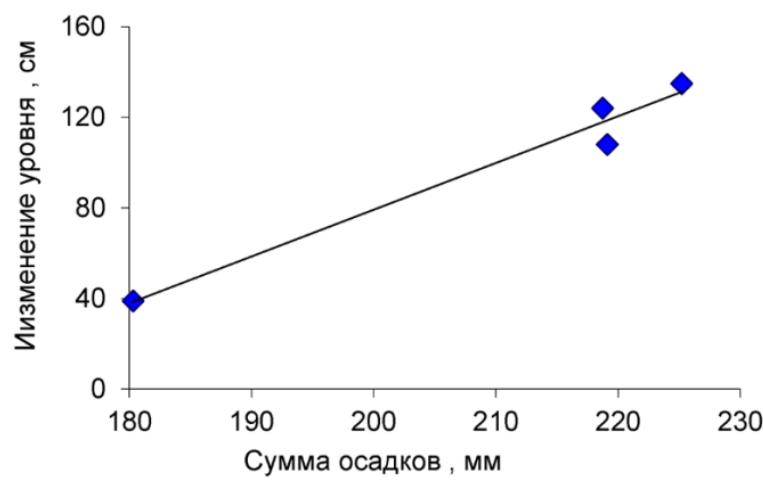

Рис. 6. Зависимость поправки на уменьшение максимального уровня в створе Абакан-Абакан от суммы зимних осадков при слабом промерзании $\left(y=2,065 x-333,86, R^{2}=0,97\right)$

Fig. 6. Dependence of correction for a decrease in maximum levels at the Abakan-Abakan site on winter precipitation amount at weak freezing $\left(y=2,065 x-333,86, R^{2}=0,97\right)$

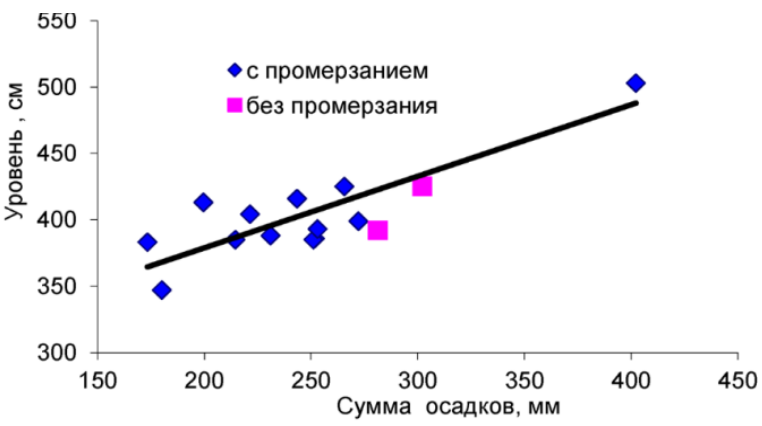

Рис. 7. Зависимость максимальных уровней (формируемых вследствие снеготаяния) в створе АбаканАбаза от суммы твердых осадков (ноябрь-март) $\left(y=0,54 x+270,98, R^{2}=0,73\right)$

Fig. 7. Dependence of snowmelt-induced maximum levels at the Abakan-Abaza site on solid precipitation amount (November-March $)\left(y=0,54 x+270,98, R^{2}=0,73\right)$

Как видим, различные условия осеннего промерзания в бассейне р. Абакан для створа Абаза не влияют на максимальные уровни, формируемые таянием снега.

При анализе максимальных уровней периода половодья в бассейне реки Абакан, обусловленных снеготаянием, установлено, что на их формирование в районе гидропоста р. Абакана-г. Абакан (предгорная равнина) значительное влияние оказывает промерзание на начальном этапе снегонакопления. В бассейне p. Абакана-г. Абакан зимы без «промерзания» (2006-2007, 2008-2009, 2012-2013, 2015-2016 гг.) выделяются большой толщиной снега на предгорной равнине перед значительными морозами. Однако для бассейнов, имеющих в подавляющем большинстве горный ландшафт (р. Абакана-г. Абаза), промерзание не является лимитирующим фактором.

Полученные данные хорошо согласуются с результатами исследования максимальных уровне периода половодья на р. Чарыш (на участке бассейна, расположенного на предгорной равнине) и на р. Ануй (бассейн - низкогорье и среднегорье).

Таким образом, условия осеннего промерзания играют определенную роль для бассейнов, в морфологии которых отмечается значительная доля предгорных равнин.

\section{Алгоритм расчета максимальных уровней периода половодья}

Последовательность этапов расчета максимальных уровней за счет снеготаяния продемонстрирована на примере 2016-2018 гг., для которых характерны различные формы графика связи суммы зимних осадков и орографической добавки и различные условия осеннего промерзания почвогрунтов:

1. Определение даты начала снегонакопления (выпадения твердых осадков). По всем метеостанциям (табл. 1) выбираются средние суточные температуры и осадки за октябрь и ноябрь. Определяется дата устойчивого перехода температуры воздуха на метеостанции через нуль (отрицательные значения), эта дата принимается за начало снегонакопления. Начало снегонакопления может наблюдаться как в октябре, так и в начале ноября.

2. Определение даты окончания периода снегонакопления. Определяется дата устойчивого перехода температуры воздуха на метеостанции через нуль (положительные значения), эта дата, не позже конца марта, принимается за окончание периода снегонакопления.

3. Если в начале снегонакопления или в марте наблюдаются оттепели, то необходима экспертная оценка потери твердых осадков. Например, коэффициент таяния снега принимается равным $3,5-4,0 \mathrm{~mm} /{ }^{\circ} \mathrm{C} /$ сут., и в соответствии с наблюдавшимися положительными температурами уменьшается количество твердых осадков.

4. Определяются суммы твердых осадков на метеостанциях за период снегонакопления.

5. Строится график связи суммы твердых осадков и орографической добавки к скорости вертикальных движений, определяется уравнение линии тренда (аналогично рис. 4).

6. По уравнению связи (шаг 5) и по значениям $\mathrm{Vz}$ (табл. 3) определяется суммы твердых осадков в каждой ячейке матрицы. При расчете суммы осадков по зависимости $y=a x+b$ возможно появление отрицательных значений. Отрицательные значения заменяются на некоторую положительную константу (в наших расчетах 10 мм).

7. Вычисляется среднее значение твердых осадков по всем ячейкам матрицы. Зима 2015-2016 гг. среднее равно 219 мм, зима 2016-2017 гг. 193 мм, зима 2017-2018 гг. - 190 мм. 
8. Проверяются условия осеннего промерзания почвогрунтов по метеостанции Абакан.

Осень 2015 г.: до значительных морозов в период с 1 по 10 ноября на метеостанции Абакан выпало 12,1 мм осадков в твердой фазе. При плотности свежеосевшего снега $0,15 \Gamma / \mathrm{cm}^{3}$ толщина снега составит $8 \mathrm{~cm}$.

Осень 2016 г.: до значительных морозов в период с 12 октября по 5 ноября на метеостанции Абакан выпало 16,7 мм осадков в твердой фазе. При плотности свежеосевшего снега 0,15 г/ $\mathrm{cm}^{3}$ толщина снега составит $11 \mathrm{~cm}$.

Осень 2017 г.: до значительных морозов в период с 9 по 15 ноября на метеостанции Абакан выпало 1,9 мм осадков в твердой фазе. При плотности свеже-

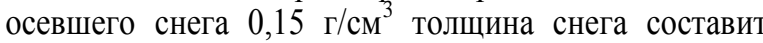
$1 \mathrm{~cm}$.

Таким образом, в расчет максимальных уровней 2016 и 2017 гг. необходимо вводить поправку на учет слабого промерзания.

По уравнению связи (рис. 5) величина максимального уровня за счет таяния снега половодья в 2016 г. без учета слабого промерзания должна быть равна 450 см, величина максимума половодья в 2017 г. (также без учета слабого промерзания) - 407 см. С учетом поправки на слабое промерзание (рис. 6) в 2016 г. максимальный уровень необходимо уменьшить на 120 см, в 2017 - на 60 см. Тогда с учетом поправок на слабое промерзание максимальный уровень в 2016 г. должен быть равен 330 см, в 2017 - $347 \mathrm{~cm}$. В 2018 г. максимальный уровень должен быть равен

\section{СПИСОК ЛИТЕРАТУРЫ}

1. Борщ С.В., Христофоров А.В. Оценка качества прогнозов речного стока. Серия: Гидрометеорологические прогнозы. М.: Гидрометеорологический НИЦ РФ, 2015. - 200 с.

2. Руководство по гидрологической практике. Т. 2. Управление водными ресурсами и практика применения гидрологических методов. - Женева: ВМО, 2012. - 324 с.

3. Бураков Д.А., Гордеев И.Н., Космакова В.Ф. Применение регрессионных зависимостей в долгосрочных прогнозах максимальных уровней воды на примере р. Енисей у г. Кызыла // Вопросы географии Сибири. Вып. 29. - Томск: Изд-во ТГУ, 2009. - C. 5-6.

4. Беляев Б.М. Оценка возможности прогнозирования максимальных уровней воды малых рек бассейна Верхней Волги // Вопросы гидрологии, геоэкологии и охраны водных объектов. Пермь: Изд. Перм. гос. нац. исслед. ун-та, 2016. - С. 123-127.

5. Георгиевский Ю.М. Краткосрочные гидрологические прогнозы. - М.: Изд. ЛПИ, 1982. - 100 с.

6. Паромов В.В., Шумилова К.А., Гордеев И.Н. Условия формирования половодья большой водности и прогноз наводнения на реке Абакан // Известия Томского политехнического университета. Инжиниринг георесурсов. - 2016. - Т. 327. № 11. - C. 57-67.

7. Hydrological risks in Western Siberia under the changing climate and anthropogenic influences conditions / V.A. Zemtsov, V.V. Paromov, S.G. Kopysov, A.V. Kouraev, S.V. Negrul // International Journal of Environmental Studies. - 2014. - V. 71. № 5. - P. 611-617.

8. Influence of atmospheric circulation on precipitation in Altai Mountains / N. Malygina, T. Papina, N. Kononova, T. Barlyaeva // Journal of Mountain Science. - 2017. - V. 14. - № 1. - P. 46-59.

9. Impacts of climate changes on water resources in Yellow River Basin, China / Y. Zhu, Z. Lin, J. Wang, Y. Zhao, F. He // Procedia Engineering. - 2016. - V. 154. - P. 687-695.
402 см. Реально максимальный уровень половодья в 2016 г. равнялся 345 см, в 2017 г. - 377 см, в 2018 г. 379 см. Таким образом, разница расчетных и наблюденных уровней не превышает 30 см.

\section{Выводы}

1. Разработана методика расчета сумм зимних (ноябрь-март) ежегодных осадков в бассейне р. Абакан, учитывающая физические особенности формирования осадков в горах, в частности орографическую добавку к скорости вертикальных движений.

2. На примере независимых данных показано, что алгоритмы расчета максимальных уровней от таяния снега за период половодья, основанные на регрессионных зависимостях, в условиях изменения циркуляции атмосферы не всегда дают адекватные результаты. Необходима их современная корректировка в связи с процессами промерзания на предгорной равнине.

3. В статье показано, что поправка на изменение уровня при промерзании зависит от суммы зимних осадков. При сумме в 180 мм поправка равна 40 см, при сумме 220 мм - 120 см. Однако требуются дополнительные данные наблюдений для получения более общей статистической зависимости.

Работа выполнена в рамках государственного задания Института водных и экологических проблем Сибирского отделения Российской академии наук (ИВЭП СО РАН).

10. Burn D.H., Whitfield P.H. Changes in cold region flood regimes inferred from long record reference gauging stations // Advances in Water Resources. - 2018. - V. 121. - P. 333-349. URL: https://doi.org/10.1016/j.advwatres.2018.08.017 (дата обращения 13.12.2020)

11. Silvestro F., Rebora N. Impact of precipitation forecast uncertainties and initial soil moisture conditions on a probabilistic flood forecasting chain // Journal of Hydrology. - November 2014. - V. 519. - P. 1052-1067.

12. Effects of snow cover on soil freezing, water movement, and snowmelt infiltration: A paired plot experiment / Y. Iwata, M. Hayashi, S. Suzuki, T. Hirota, S. Hasegawa // Water resources research. - 2010. - V. 46. - № 9. - Article number W09504. URL: https://doi.org/10.1029/2009WR008070 (дата обращения 13.12.2020)

13. Effects of soil water and heat relationship under various snow cover during freezing-thawing periods in Songnen Plain, China / Q. Fu, R. Hou, T. Li, R. Jiang, P. Yan, Z. Ma, Z. Zhou // Scientific Reports. - 2018. - V. 8. - № 1. - Article number 1325. URL: https://doi.org/10.1038/s41598-018-19467-у (дата обращения 13.12.2020).

14. Effects of preferential flow on snowmelt partitioning and groundwater recharge in frozen soils / A.A. Mohammed, I. Pavlovskii, E.E. Cey, M. Hayashi // Hydrology and Earth System Science. 2019. - V. 23. - P. 5017-5031. URL: https://doi.org/10.5194/hess-23-5017-2019 (дата обращения 13.12.2020).

15. Effect of snowmelt infiltration on groundwater recharge in a seasonal soil frost area: a case study in Northeast China / X. Du, M. Fang, H. Lv, T. Cheng, P. Hong, C. Liu // Environmental Monitoring and Assessment. - 2019. - V. 191. - Article Number 151. - P. 1-11. URL: https://doi.org/10.1007/s10661-019-7285-7 (дата обращения 13.12.2020).

16. Дюкарев Е.А. Прогноз глубины промерзания почвы с помощью простейшей регрессионной модели // Вестник Томского государственного университета. - 2014. - № 387. - С. 266-270. 
17. Состояние геологической среды (недр) территории Сибирского федерального округа в 2016 году. Информационный бюллетень. Вып. 13. АО «Томск-геомониторинг». - Томск: ООО «Д-принт», 2017. - 174 с

18. Состояние геологической среды (недр) территории Сибирского федерального округа в 2018 году. Информационный бюллетень. Вып. 15. Филиал «Сибирский региональный центр ГМСН», ФГБУ «Гидроспецгеология». - Томск: ООО «Д-принт», 2019. - 218 с

19. Галахов В.П. Условия формирования и расчет максимальных снегозапасов в горах. - Новосибирск: Наука, 2003. - 104 с.

20. Ресурсы поверхностных вод СССР. Т. 16. Ангаро-Енисейский район. Вып. 1. Енисей под ред. А.П. Муранова. - Л.: Гидрометеоиздат, 1973. - $724 \mathrm{c}$

21. Многолетние данные о режиме и ресурсах поверхностных вод суши. Т. 1. Вып. 12. Бассейны Енисея (без бассейна Ангары) и Пясины. - Л.: Гидрометеоиздат, 1985. - 463 с.

22. Ежегодные данные о режиме и ресурсах поверхностных вод суши: Ч. 1. Реки и каналы. Т. 1: Вып. 12. Бассейны Енисея (без бассейна Ангары) и Пясины. - Л.: Гидрометеоиздат, 1966-1987. -23 c.

23. Метеорологический ежемесячник. Ч. 2. Вып. 21. Краснояр. террит. упр. по гидрометеорологии и контролю природ. среды. - Новосибирск, 1966-1987.

24. Булыгина О.Н., Разуваев В.Н., Александрова Т.М. «Описание массива данных суточной температуры воздуха и количества осадков на метеорологических станциях России и бывшего CCCP (TTTR)» Свидетельство о государственной регистрации базы данных № 2014620942. URL: http://meteo.ru/data/162temperature-precipitation\#описание-массива-данных (дата обращения: 13.12.2020).

25. Справочно-информационный портал «Погода и климат». URL: http://www.pogodaiklimat.ru (дата обращения: 17.02.2020).

26. «Расписание Погоды». URL: https://rp5.ru (дата обращения 13.12.2020).

27. Автоматизированная информационная система государственного мониторинга водных объектов. URL: https://gmvo, skniivh.ru (дата обращения: 13.12.2020).
28. Георгиевский Ю.М., Шаночкин С.В. Гидрологические прогнозы. - СПб: РГМУ, 2007. -435 с.

29. Роджерс Р.Р. Краткий курс физики облаков. - Л.: Гидрометеоиздат, 1979. - $232 \mathrm{c}$

30. Матвеев Л.Т. Курс общей метеорологии. Физика атмосферы. Л.: Гидрометеоиздат, 1984. - 752 c.

31. Galakhov V.P., Lovtskaya O.V., Mardasova E.V. Stochastic model for calculation of maximum flood stage in Charysh river using the annual winter precipitation // Eurasian journal of mathematical and computer applications. - 2018. - V. 6. - № 3. P. 34-44.

32. Прогноз максимальных уровней реки Чарыш в период снеготаяния / В.П. Галахов, Е.С. Попов, Е.В. Мардасова, А.В. Плехова // Известия Алтайского отделения русского географического общества. - 2016. - Т. 42. - № 3. - С. 38-44.

33. Bajjali W. ArcGIS for Environmental and Water Issues (eBook). Springer International Publishing AG. - 2018. - 348 p. URL: https://doi.org/10.1007/978-3-319-61158-7 (дата обращения 13.12.2020)

34. Галахов В.П., Легачева Н.М., Рудыка И.Ю. Оценка осадков половодья с помощью орографической добавки к скорости вертикальных движений (на примере реки Абакан) // Известия Алтайского отделения русского географического общества. 2017. - T. 44. - № 1. - C. 60-66.

35. Характерные уровни воды рек, каналов, озер и водохранилищ (погодичные данные). Ч. 1. Реки и каналы. Вып. 12. Бассейны Енисея (без бассейна Ангары) и Пясины. - Л.: Гидрометеоиздат, 1989. - 108 с.

36. Карлберг К. Регрессионный анализ в Microsoft Excel. - M.: Диалектика, 2017. - 400 c.

37. Галахов В.П., Самойлова С.Ю., Мардасова Е.В. Влияние условий формирования снежного покрова на сток половодья горной реки (на примере бассейна реки Ануй) // Известия Алтайского отделения русского географического общества. 2020. - T. 56. - № 1. - С. 24-33.

Поступила 01.03.2021 г.

\section{Информация об авторах}

Галахов В.П., кандидат географических наук, старший научный сотрудник Института водных и экологических проблем СО РАН.

Ловцкая О.B., старший научный сотрудник Института водных и экологических проблем СО РАН.

Mapdacoвa E.B., старший преподаватель кафедры экономической географии и картографии Института географии Алтайского государственного университета. 
UDC 556.161:556.166

\title{
CLIMATE CHANGE EFFECT ON MAXIMUM FLOOD STAGES IN ABAKAN RIVER
}

\author{
Vladimir P. Galakhov 1 , \\ galahov@iwep.ru \\ Olga V. Lovtskaya ${ }^{1}$ \\ lov@iwep.ru \\ Elena V. Mardasova², \\ mardasova_ev@mail.ru \\ 1 Institute for Water and Environmental Problems SB RAS, \\ 1, Molodezhnaya street, Barnaul, 656038, Russia. \\ 2 Altai State University, \\ 61, Lenin avenue, Barnaul, 656049, Russia.
}

The study topicality relates to the effect of climate changes and increased recurrence of dangerous hydrological events on rivers of southern Siberia. The observed and predicted changes in flood regimes are caused by a variety of factors and require different approaches in order to characterize the types of these changes.

The aim of the study is stochastic modeling of solid precipitation total in the Abakan river basin, establishing relationship between precipitation and maximum water levels in the Abakan river during the flood period under spatial and temporal variability of hydrometeorological factors.

Methods: comprehensive geographical and hydrometeorological analysis, dependence establishment based on long-term hydrometeorological observations using mathematical statistics methods, methods (developed by V.P. Galakhov) for estimating precipitation total in the basin with regard for orographic correction to the velocity of vertical movements in the frontal zone.

Results. The crucial factor in the formation of maximum flood levels is winter precipitation amount. Heavy rainfalls during flood recession may significantly influence the maximum water levels. However, climate changes of recent decades in river mountain basins of southwestern and eastern Siberia are evidence of dependences between autumn soil freezing and formation of snowmelt-induced maximum stages. In some years during the flood period, decreased maximum water levels are probable in basins with prevailing foothill plains, unlike those with overwhelmingly mountainous landscapes. We have developed a method for calculating winter annual precipitation total in the Abakan basin taking into account physical features of precipitation formation in the mountains, in particular the orographic correction to the velocity of vertical movements. The independent data suggest that algorithms for calculating snowmelt-induced maximum stages based on regression dependencies do not always give adequate results, therefore updating with regard for freezing processes in the foothill plain is required. Besides, extra observation data are called for obtaining the general statistical dependence.

Key words:

Abakan River Basin, winter precipitation, orographic correction, velocity of vertical movements, maximum levels.

The research was carried out within the State task of the Institute of Water and Ecological Problems SB Russian Academy of Science.

\section{REFERENCES}

1. Borshch S.V., Khristoforov A.V. Otsenka kachestva prognozov rechnogo stoka. Seriya: Gidrometeorologicheskie prognozy [Forecast evaluation of river runoff quality. Series: Hydrometeorological forecasts] Moscow, Gidrometeorologicheskiy NITS RF Publ., 2015. 200 p.

2. Rukovodstvo po gidrologicheskoy praktike. T.2. Upravlenie vodnymi resursami i praktika primeneniya gidrologicheskikh metodov [Guide to hydrological practice. Vol. 2. Water management and hydrological methods application in practice]. Geneva, WMO, 2012. $324 \mathrm{p}$.

3. Burakov D.A., Gordeev I.N., Kosmakova V.F. Primenenie regressionnykh zavisimostey $\mathrm{v}$ dolgosrochnykh prognozakh maksimalnykh urovney vody na primere r. Yenisey u g. Kyzyla [Application of regression dependencies in long-term forecasts of maximum levels by the example of Yenisei river at Kyzyl]. Voprosy geografii Sibiri, 2009, no. 29, pp. 5-6.

4. Belyaev B.M. Otsenka vozmozhnostey prognozirovaniya maksimalnykh urovney vody malykh rek basseyna Verkhney Volgi [Assessment of probable forecasting maximum levels in small rivers of the Upper Volga basin]. Voprosy gidrologii, geoekologii i okhrany vodnykh obyektov. Materialy regionalnoy nauchnoprakticheskoy konferentsii [Hydrology, geoecology and water protection issues. Proceedings of Interregional Scientific-Practical Conference]. Perm, PSNRU Publ., 2016. pp. 123-127.

5. Georgiyevskiy Yu.M. Kratkosrochnyye gidrologicheskie prognozy [Short-term hydrological forecasts]. Moscow, LPI Publ., 1982. 100 p.
6. Paromov V.V., Shumilova K.A., Gordeev I.N. Conditions of formation of highwater flood and flood forecast on the river Abakan. Bulletin of the Tomsk Polytechnic University. Geo Assets Engineering, 2016, vol. 327, no. 11. pp. 57-67. In Rus.

7. Zemtsov V.A., Paromov V.V., Kopysov S.G., A.V. Kouraev, Negrul S.V. Hydrological risks in Western Siberia under the changing climate and anthropogenic influences conditions. International Journal of Environmental Studies, 2014, vol. 71, no. 5, pp. 611-617.

8. Malygina N., Papina T., Kononova N., Barlyaeva T. Influence of atmospheric circulation on precipitation in Altai Mountains. Journal of Mountain Science, 2017, vol. 14, no. 1, pp. 46-59.

9. Zhu Y., Lin Z., Wang J., Zhao Y, He F. Impacts of climate changes on water resources in Yellow River Basin. China Procedia Engineering, 2016, vol. 154, pp. 687-695.

10. Burn D.H., Whitfield P.H. Changes in cold region flood regimes inferred from long record reference gauging stations. Advances in Water Resources, 2018, vol. 121, pp. 333-349. Available at: https://doi.org/10.1016/j.advwatres.2018.08.017 (accessed 13 December 2020)

11. Silvestro F., Rebora N. Impact of precipitation forecast uncertainties and initial soil moisture conditions on a probabilistic flood forecasting chain. Journal of Hydrology, 2014, vol. 519, pp. 1052-1067.

12. Iwata Y., Hayashi M., Suzuki S., Hirota T., Hasegawa S. Effects of snow cover on soil freezing, water movement, and snowmelt infiltration: a paired plot experiment. Water resources research, 2010, vol. 46, no 9. Available at: https://doi.org/10.1029/2 009WR008070 (accessed 13 December 2020). 
13. Fu Q., Hou R., Li T., Jiang R., Yan P., Ma Z., Zhou Z. Effects of soil water and heat relationship under various snow cover during freezing-thawing periods in Songnen Plain, China. Scientific Reports, 2018, vol. 8, no. 1. Available at: https://doi.org/10.1038/ s41598-018-19467-y (accessed 13 December 2020).

14. Mohammed A.A., Pavlovskii I., Cey E.E., Hayashi M. Effects of preferential flow on snowmelt partitioning and groundwater recharge in frozen soils. Hydrology and Earth System Science, 2019, vol. 23, pp. 5017-5031. Available at: https://doi.org/10.5194/hess23-5017-2019 (accessed 13 December 2020).

15. Du X., Fang M., Lv H., Cheng T., Hong P., Liu C. Effect of snowmelt infiltration on groundwater recharge in a seasonal soil frost area: a case study in Northeast China. Environmental Monitoring and Assessment, 2019, vol. 191, no. 3. Available at: https://doi.org/10.1007/s10661-019-7285-7 (accessed 13 December 2020).

16. Dyukarev E.A. Soil freezing depth forecast using simple regression model. Tomsk State University Journal, 2014, no. 387, pp. 266-270. In Rus.

17. Sostoyanie geologicheskoy sredy (nedr) territorii Sibirskogo federalnogo okruga v 2016 godu [State of the geological environment (subsoil) of the Siberian Federal District territory in 2016]. Informatsionnyi byulleten. Vyp. 13. Tomskgeomonitoring. Tomsk, OOO D-print Publ., 2017. 174 p.

18. Sostoyanie geologicheskoy sredy (nedr) territorii Sibirskogo federalnogo okruga v 2018 godu [State of the geological environment (subsoil) of the Siberian Federal District territory in 2016]. Informatsionnyi byulleten. Vyp. 15. Filial «Sibirskiy regionalny tsentr GMSN», FGBU «Gidrospetsgeologiya» Filial «Sibirskiy regionalny tsentr GMSN», FGBU «Gidrospetsgeologiya». Tomsk, OOO D-print Publ., 2019. 218 p

19. Galakhov V.P. Usloviya formirovaniya i raschet maksimalnykh snegozapasov $v$ gorakh [Conditions for formation and estimation of maximum snow storage in mountains]. Novosibirsk, Nauka Publ., 2003. 104 p.

20. Resursy poverkhnostnykh vod SSSR. T. 16. Vyp. 1. AngaroYeniseyskiy rayon. Yenisey [Surface water resources in the USSR Vol. 16. Iss. 1. Angaro-Yeniseyskiy region. Yenisey]. Ed. by A.P. Muranov. Leningrad, Gidrometeoizdat Publ., 1973. 724 p.

21. Mnogoletnie dannye o rezhime i resursakh poverkhnostnykh vod sushi. T. 1. Vyp. 12. Basseyny Yeniseya (bez basseyna Angary) $i$ Pyasiny [Long-term data of surface water regime and resources. Vol. 1. Iss. 12. Basins of the Yenisei (without the Angara basin) and Pyasina]. Leningrad, Gidrometeoizdat Publ., 1985. 463 p.

22. Ezhegodnye dannye $v$ rezhime $i$ resursakh poverkhnostnykh vod sushi: Ch. 1. Reki i kanaly. T. 1: Vyp. 12. Basseyny Yeniseya (bez basseyna Angary) i Pyasiny [Annual data of surface water regime and resources: P. 1. Rivers and canals. Vol. 1. Iss. 12. Basins of the Yenisei (without the Angara basin)]. Leningrad, Gidrometeoizdat Publ., 1966-1987. 23 p.

23. Meteorologicheskiy ezhemesyachnik [Meteorological Monthly] Ch. 2. Vyp. 21. Novosibirsk, 1966-1987.

24. Bulygina O.N., Razuvaev V.N., Alexandrova T.M. Opisanie massiva dannykh sutochnoy temperatury vozdukha $i$ kolichestva osadkov na meteorologicheskikh stantsiyakh Rossii $i$ byvshego
SSSR. Svidetelstvo o gosudarstvennoy registratsii bazy dannykh no. 2014620942. [Description of the data array of the daily air temperature and the amount of precipitation at Russia and the former USSR weather stations (TTTR). Certificate of the database state registration No 2014620942]. Available at: http://meteo.ru/ data/162-temperature-precipitation (accessed: 13 December 2020).

25. Spravochno-infomatsionny portal «Pogoda i klimat» [Reference and information portal «Weather and Climate»]. Available at: http://www.pogodaiklimat.ru (accessed 13 December 2020).

26. Raspisanie pogody [Reliable prognosis]. Available at: https://rp5.ru (accessed 13 December 2020).

27. Avtomatizirovannaya informatsionnaya sistema gosudarstvennogo monitoring vodnykh obyektov [Automated information system for state monitoring of water bodies]. Available at: https://gmvo.skniivh.ru (accessed 13 December 2020).

28. Georgievskiy Yu.M., Shanochkin S.V. Gidrologicheskie prognozy [Hydrological forecasts]. St-Peterburg, RGMU Publ., 2007. 435 p.

29. Rogers R.R. Kratkiy kurs fiziki oblakov [A short course in cloud physics]. Leningrad, Gidrometeoizdat Publ., 1979. 232 p.

30. Matveev L.T. Kurs obshchey meteorologii. Fizika atmosfery [The course of general meteorology. Physics of Atmosphere]. Leningrad, Gidrometeoizdat Publ., 1984. 752 p.

31. Galakhov V.P., Lovtskaya O.V., Mardasova E.V. Stochastic model for calculation of maximum flood stage in Charysh River using the annual winter precipitation. Eurasian journal of mathematical and computer applications, 2018, vol. 6, no. 3, pp. 34-44.

32. Galakhov V.P., Popov E.S., Mardasova E.V., Plekhova A.V. Forecast of maximum stage in Charysh river during the snowmelt. Bulletin of the Altay branch of the Russian Geographical society, 2016, vol. 42, no. 3, pp. 38-44. In Rus.

33. Bajjali W. ArcGIS for environmental and water issues (eBook). Springer International Publishing AG, 2018. 348 p. Available at: https://doi.org/10.1007/978-3-319-61158-7 (accessed 13 December 2020).

34. Galakhov V.P., Legacheva N.M., Rudyka I.Yu. Flood precipitation estimate based on orographic change in vertical air motion (river Abakan as a case study). Bulletin of the Altay branch of the Russian Geographical society, 2017, vol. 44, no. 1, pp. 60-66. In Rus.

35. Kharakternye urovni vody rek, kanalov, ozer i vodokhranilishch (pogodichnye dannye). Ch. 1. Reki i kanaly. Vyp. 12. Basseyny Yeniseya (bez basseyna Angary) $i$ Pyasiny. [Typical water levels of rivers, canals, lakes and reservoirs (year data). P. 1. Rivers and canals. Iss. 12. Basins of the Yenisei (without the Angara basin) and Pyasina]. Leningrad, Gidrometeoizdat Publ., 1989. 108 p.

36. Carlberg C. Regression Analysis Microsoft Excel. USA, Pearson Higher Ed, 2016. 351 p.

37. Galakhov V.P., Samoylova S.Yu., Mardasova E.V. Effect of a ratio of large morphological units of a mountain basin on snowmelt runoff. Bulletin of the Altay branch of the Russian geographical society, 2020, vol. 56, no. 1, pp. 24-33. In Rus.

Received: 1 March 2021.

\section{Information about the authors}

Vladimir P. Galakhov, Cand. Sc., senior researcher, Institute for Water and Environmental Problems SB RAS.

Olga V. Lovtskaya, senior researcher, Institute for Water and Environmental Problems SB RAS

Elena V. Mardasova, senior lecturer, Altai State University. 